\title{
Studies on combined effect of Aeromonas hydrophila and cadmium on lipid peroxidation and antioxidant status in selected tissues of Indian freshwater major carp, Catla catla: role of silver nanoparticles
}

\author{
T. Kiran Reddy, T.N.V.K.V. Prasad ${ }^{1}$, S. Janardana Reddy* \\ Department of Fishery Science and Aquaculture,Sri Venkateswara University, Tirupati-517 502, AP, INDIA \\ ${ }^{I}$ Department of Soil Sciences, Sri Venkateswara Agricultural College, Tirupati-517 502, AP, INDIA
}

\begin{abstract}
The present study was aimed to evaluate the effect of dual stressors cadmium (Cd) and Aeromonas hydrophila (AH) on pro-and antioxidant status in gills, kidneys and liver tissues of fishes, Catla catla treated with or without silver nano-particles. Significant elevation in the lipid peroxidation levels with a significant decrease in the activity levels of superoxide dismutase, catalase, glutathione-S-transferase in were observed in gills, kidneys and liver tissues of fishes exposed to individual and/or in combination with $\mathrm{Cd}$ and $\mathrm{AH}$ over controls. However, significant elevation in the activity levels of xanthine oxidase was observed in the selected tissues of fishes treated with $\mathrm{Cd}, \mathrm{AH}$ and $\mathrm{Cd}+\mathrm{AH}$ over controls. On the other hand, AgNPs showed a reversal effect on $\mathrm{Cd}$-, $\mathrm{AH}$ - and $\mathrm{Cd}+\mathrm{AH}$-induced alterations in lipid peroxidation levels and antioxidant enzymes in gills, kidneys and liver tissues of fishes over their respective controls. No significant changes were observed in lipid peroxidation levels and antioxidant enzymes in selected tissues of fishes exposed to AgNPs alone as compared to untreated fishes. From the findings it is clear that AgNPs protects gills, kidneys and liver against $C d$ and $A H$ induced oxidative stress. Further studies in this direction might definitely augment the use of nano-based compounds as therapeutic candidates in fisheries.
\end{abstract}

KEY WORDS- A. hydrophila, Catla catla, lipid peroxidation, antioxidant enzymes, silver nanoparticles

\section{INTRODUCTION}

Food sector is an important area of public concern. Among food sector industries, aquaculture occupies a strategic position all over the world (1). However, waterborne diseases, including bacterial infections affect aquaculture industry and in particular fisheries thereby causes economic loses to aqua-farmers (2). Among a range of bacterial diseases, Aeromonas hydrophila (AH) mediated diseases severely affect fisheries (3). Indigenous fishes such as Catla catla is one of the commercially and highly cultivable species across India (4). Previously, it has been indicated that $\mathrm{AH}$ negatively affect spleen, liver, kidneys and gills and eventually interferes with immune system and physiological events in fishes including $C$. catla (5-8). Thus, it is obvious that $A$. hydrophila adversely affects all vital organs and subsequently leads to death of fishes. To overcome $\mathrm{AH}$ mediated adverse effects, currently antimicrobial agents such as terramycin and Remet-30 are widely used. However, due to frequent use of these antibiotics in fisheries, resistance developed by bacteria against these antibiotics is a major limiting factor to prevent and control AH mediated infections. Thus, it is important to develop novel alternative strategies to control Aeromonas infections in fishes. On the other hand, toxic impact of heavy metals including cadmium (Cd) in fisheries is increasing at an alarming rate (9). Earlier it has been indicated that cadmium has ability to bioaccumulate in fish organs and exerts negative effects on hematological and physiological aspects of fishes (10). During recent past, exposure of aquatic organisms to dual stressors such as physical and/or biological factors is unavoidable. However, studies related to the exposure of fishes to dual stressors such as bacteria and heavy metals (eg: Cd) are not well defined.Recently, the role of nanotechnology in pharmaceutical area and in particular against bacterial infections is well appreciated (11). This aspect attracted the attention of aqua based farmers all over the world and as a result the application of nano based particles in the field of aquaculture is gaining importance day-by-day. Silver nano-particles (AgNPs) are classical nano-based compounds that are widely used as antibacterial agent against broad spectrum of bacteria (12). Earlier, it has also been reported that AgNPs particles show potential antimicrobial efficacy against AH bacteria (13). Previously, we demonstrated that silver nanoparticles play a pivotal role in energy metabolism in fishes infected with $\mathrm{AH}(8)$. Thus, it seems apparent that AgNPs at least in part cross-talk with energy metabolism in fishes during stress conditions. Therefore, in view of the above facts, the present study was further aimed to evaluate whether AgNPs has any role against combined effect of cadmium and $\mathrm{AH}$ induced alterations in pro-and antioxidant status in fishes. 


\subsection{Collection and maintenance of fishes}

\section{MATERIALS AND METHODS}

Catla catla $(10.0 \pm 0.52 \mathrm{~cm}$ in length and $11.0 \pm 1.2 \mathrm{~g}$ in weight) were selected as experimental fishes for the present study. Catla catla $(10.0 \pm 0.52 \mathrm{~cm}$ in length and $11.0 \pm 1.2 \mathrm{~g}$ in weight) were purchased from A.P. Government Central Fish Farm, Kalyani dam, Chittoor Distrtict, AP, INDIA. Fishes of male sex were maintained in cement aquaria (each 1,000 liters capacity), where they received un-chlorinated continuous gentle flow of water from a deeply sunk bore well within University campus. Fishes were maintained under controlled laboratory conditions. All the fishes were acclimated for at least two weeks and fed ad libitum fish diet in a laboratory conditions at the ambient, uncontrolled temperature of $28 \pm 2^{\circ} \mathrm{C}$ under the $12 \mathrm{~h}: 12 \mathrm{~h}$ light:dark conditions. The fish were starved $24 \mathrm{~h}$ prior to the start of the experiments in order to avoid metabolic variations due to diet, if any.

\subsection{Bacterial strain}

A. hydrophila was obtained from Microbial Type Culture Collection and Gene Bank (MTCC) Institute of Microbial Technology, Sector 39-A, Chandigarh, India. After obtaining bacteria, it was cultured in tryptone soya broth (Himedia) for $24 \mathrm{~h}$ at $37^{\circ} \mathrm{C}$. After incubation period, the culture was centrifuged at $800 \mathrm{~g}$ for $15 \mathrm{~min}$ at $4^{\circ} \mathrm{C}$. The packed cells were washed with phosphate buffered saline (PBS; $\mathrm{pH}$ 7.2) twice and then the required dose was prepared in PBS. The bacterial suspension was prepared to $1 \times 10^{9}$ Colony Forg Units as determined using a Neubauer haemocytometer.

\subsection{Ag nano-particles}

In the present study, citrate coated $\mathrm{Ag}$ nanoparticles were prepared using chemical routes with an average size of $30 \mathrm{~nm}$. The measured zeta potentials of prepared Ag nanoparticles were formed to be $-42 \mathrm{mv}$. AgNPs stocks were prepared by suspending $100 \mathrm{mg}$ of citrate coated AgNPs in 1 litre millipore water and mixed well by sonicating for at least 30 minutes. After, sonication the dilutions were prepared as required.

\subsection{Experimental design}

\section{Control group}

The fishes were randomly allocated into following groups:

Group 1

\section{Experimental Groups}

Group 2

Group 3

Group 4

Group 5

Group 6

Group 7

Group 8

: $\quad$ Cadmium exposed fishes $(\mathrm{n}=10)$

fishes $(n=10)$
Fishes maintained on normal water $(\mathrm{n}=10)$

Aeromonas hydrophila infected fishes $(\mathrm{n}=10)$.

Combined treatment of cadmium intoxication and A. hydrophila infected

: $\quad$ Silver nanoparticles (AgNPs) exposed fishes $(\mathrm{n}=10)$

: $\quad$ Cadmium + AgNPs treated fishes $(\mathrm{n}=10)$

: $\quad$ A. hydrophila infection $+\mathrm{AgNPs}$ treated fishes $(\mathrm{n}=10)$

: $\quad$ cadmium intoxication + A. hydrophila infection + AgNPs treated fishes $(\mathrm{n}=10)$

Fishes in groups 2, 4, 6 and 8 received daily sub lethal concentration of cadmium chloride (based on probit analysis for $96 \mathrm{hrs} \mathrm{LC}_{50}$ the concentration of $\mathrm{CdCl}_{2}$ to Catla catla was determined as $21.53 \mathrm{mg} / \mathrm{l}$; Therefore for the present study, $1 / 5^{\text {th }} \mathrm{LC}_{50} 4.036 \mathrm{mg} / \mathrm{l}$ was selected as test dose). The heavy metal containing water medium was changed at every $24 \mathrm{~h}$ in order to maintain a constant sub lethal concentration of heavy metal. In the present study, 1/10th concentration of $100 \mu \mathrm{g}$ of $\mathrm{AgNPs} / \mathrm{L}$ was selected as test dose. The dose selection was based on earlier reports $(8,14)$. The quantity of silver in the selected concentrations was determined by atomic absorption spectroscopy available in Department of Soil Sciences, S.V. Agricultural College, Tirupati, AP, INDIA. Fishes in groups 5 to 8 were exposed to AgNPs at selected concentrations. The AgNPs containing medium was changed at every $24 \mathrm{~h}$. Fishes in groups 3, 4, 7 and 8 were intramuscularly injected just below the dorsal fin with $A$. hydrophila $\left(1 \times 10^{9} \mathrm{CFU} / 50 \mu 1\right.$ of $\left.0.85 \% \mathrm{NaCl}\right)$. The dose selection was based on histological alterations of selected tissues and also based on previous studies $(7,8)$. Disinfection was performed before injections using $70 \%$ ethanol and sterile and disposable insulin syringes were used for injection purposes. In the present study, respective controls were also maintained along with experimental groups.

The experimental period was about fourteen days. After completion of experimental period, all the fishes in the groups were euthanized and selected tissues were immediately isolated, washed, blotted and weighed using Shimadzu electronic balance nearest to milligram and stored at $-80^{\circ} \mathrm{C}$ until further use. 


\subsection{Antioxidant enzymes}

For the present study the activity levels of antioxidant enzymes such as superoxide dismutase, catalase, xanthine oxidase and glutathione- $S$-transferase were assayed in gills, liver and kidney tissues of control and experimental fishes.

The organs were homogenized in 4 volumes of homogenizing buffer $(50 \mathrm{mM}$ Tris- $\mathrm{HCl}$ mixed with $1.15 \% \mathrm{KCl}$ and $\mathrm{pH}$ adjusted to 7.4 ), using a Teflon homogenizer. The resulting homogenate was centrifuged at $4,000 \mathrm{~g}$ for $15 \mathrm{~min}$. to remove cell debris. The supernanant was collected and again centrifuged at $16,000 \mathrm{~g}$ for 45 minutes at $4{ }^{\circ} \mathrm{C}$ to obtain the supernatant fraction. The antioxidant enzymes and lipid peroxidation levels were assayed using the supernatant fraction.

Glutathione $S$-transferase (GST) activity was determined by the method of Habig et al. (15) using 1 chloro 2, 4 dinitrobenzene as substrate and the activity levels of GST is expressed as nmoles of GSH-CDNB conjugate formed/min/mg protein. Superoxide dismutase (SOD) activity was determined by measuring the inhibition of auto-oxidation of epinephrine as described by Misra and Fridovich et al. (16) and the units of SOD were expressed as units/mg protein. One unit of SOD activity is the amount of SOD required to cause $50 \%$ inhibition of adrenaline autooxidation. The activity of catalase (CAT; 17) was determined using hydrogen peroxide as substrate and the activity was expressed as $\mu$ moles of hydrogen peroxide decomposed/mg protein/min. Xanthine oxidase (XOD) was determined by the method described by Srikanthan and Krishnamurthy (18) using xanthine as substrate. The units of XOD were expressed as $\mu$ moles of formazan formed / $\mathrm{mg}$ protein / hour. Lipid peroxidation (LPx) was measured for the content of malondialdehyde (MDA). LPx was measured using the thiobarbituric acid (TBA) assay by the method of Hiroshi et al. (19). The units of LPx were expressed as nmoles of MDA formed/hour/g tissue. All the assays were run in triplicates.

\subsection{Estimation of proteins}

The protein content in the enzyme source was estimated by the Lowry et al. (20) using Folin phenol reagent using bovine serum albumin as standard.

\section{7. $\quad$ Statistics}

The data were presented as mean \pm S.D. Analysis of variance (one way ANOVA) followed by Dunnet's test was used to analyze the data statistically. The differences were considered to be significant at $p<$ 0.01. All statistical tests were performed using Statistical Package for Social Sciences (SPSS Inc., Chertsey, UK).

\subsection{General toxicity}

\section{RESULTS} excluded.

No mortality was observed in any of the controls and experimental groups. None of the fishes were

\subsection{Effect of combined effect of cadmium+A. hydrophila on lipid peroxidation levels in selected tissues of fishes treated with or without AgNPs}

No significant changes in the LPx levels were observed in gills, liver and kidneys of fishes maintained in water containing $1 / 10^{\text {th }}$ concentrations of $100 \mu \mathrm{g} / \mathrm{l}$ of AgNPs as compared to control fishes (Table 1). Cadmium treated and $A$. hydrophila infected fishes showed a significant increase in the LPx levels of selected tissues over their respective controls. Furthermore, combined effect of cadmium $+A$. hydrophila showed accelerated increase in the LPx levels of selected tissues in fishes. On the other hand, AgNPs showed a significant decrease in the LPx levels of selected tissues in individual and/or combination of cadmium intoxicated and A. hydrophila infected fishes (Table 1).

\subsection{Effect of combined effect of cadmium+A. hydrophila on the activity levels of antioxidant enzymes in selected tissues of fishes treated with or without AgNPs}

Significant $(\mathrm{p}<0.001)$ decrease in the activity levels of SOD, GST and CAT were observed in gills, kidney and liver tissues of $\mathrm{Cd}$ intoxicated and $\mathrm{AH}$ infected fishes (Table 1). However, a significant increase in the in the activity levels of XOD was observed in gills, kidney and liver tissues of $\mathrm{Cd}$ intoxicated and $\mathrm{AH}$ infected fishes (Table 1). However, the activity levels of SOD, XOD, GST and CAT were drastically reduced in selected tissues of $\mathrm{Cd}+\mathrm{AH}$ treated fishes as compared to their respective controls. Interestingly, AgNPs showed reversal effects on the activity levels SOD, XOD, CAT and GST in selected tissues of individual and/or combined effect of $\mathrm{Cd}$ treatment and $\mathrm{AH}$ infection. However, no significant changes were observed in the activity levels of SOD, XOD, CAT and GST in gills, kidneys and liver tissues of AgNPs alone treated fishes as compared to untreated fishes. 


\section{DISCUSSION}

The role of nanotechnology in aquaculture and in particular fisheries is well acknowledged (21). However, concerns are growing day-by-day towards the usage of nanoproducts in aquaculture (21) as they have been associated with toxic effects. Thus, understanding the mechanisms of nanoparticles in the physiology of fishes provide valuable information in the management of nanoparticles in fisheries. So far, studies related to the AgNPs have been very variable and depend on the type and nature of AgNPs, the concentration tested, size, mode of exposure and the biological test species. For example, nanoparticles with various metal combinations including AgNPs and silicon dioxide NPs negatively affect hatching of zebra fish embryos (22) and leads to alterations in the antioxidant enzymes (23). On the other hand, no significant changes were observed in the LPx levels in gills, liver and kidneys of rainbow trout, Oncorhynhus myksis treated with AgNPs (14). Previously, we demonstrated that citrate-coated AgNPs plays an important role in energy metabolism as evidenced by a balance between aerobic to anaerobic marker enzymes succinate dehydrogenase and lactate dehydrogenase, respectively in $\mathrm{AH}$ infected fishes (8). Further, titanium dioxide nanoparticles protect silkworm, Bombyx mori against phoxim induced oxidative stress and neurotoxicity $(24,25)$. Thus, it seems obvious that response of biological systems towards different combinations of NPs differ at the perspective of toxicological aspects.

In the present study, it is clearly evident that AgNPs showed reversal effects against Cd intoxicationand $\mathrm{AH}$ infection-induced changes in the activity levels of pro-and antioxidant status in the gills, liver and kidneys of fishes, Catla catla. It is well known that a balance between generation of free radicals and intrinsic antioxidant system is crucial for a range of physiological functions. In the present study, Cd intoxication and $\mathrm{AH}$ infection alone or in combination showed reduction in the activity levels of antioxidant enzymes such as SOD, GST and CAT in gills, liver and kidneys of fishes. On the other hand, LPx levels were significantly enhanced in these tissues of fishes exposed to $\mathrm{Cd}$ alone or in combination with $\mathrm{AH}$ infection. The results are in consonance with previous reports (26-28). It is well known that $\mathrm{Cd}$ severely affects structural and functional integrity of tissues through oxidative stress. Previously, it has been shown that $\mathrm{Cd}$ has ability to compete with essential metals in protein-binding sites leading to triggering release of ferrous and cuprous ions thereby elevating the levels of reactive oxygen species (ROS) (29). In addition, it has been reported that Cd negatively targets mitochondrial electron transport, and as a result shifts electron directly to oxygen which eventually leads to generation of (ROS) and causes LPx mediated damage in liver, kidney and gills (30). On the other hand, AH infection also induced oxidative stress in selected tissues of fishes by elevating the levels of LPx. The results are in agreement with earlier studies (31). This might be due to deterioration of structural integrity of tissues $(8,31)$.

SOD and CAT acts as cyclic enzymes to counterattack superoxides and hydroperoxides, respectively (32). In the present study, the reduction in the activity levels of SOD indicates improper removal of superoxides and CAT indicates loss of its activity to mitigate hydrogen peroxide in gills, kidneys and liver of Cd intoxicated and $\mathrm{AH}$ infected fishes. Further, glutathione related enzymes such as GST plays an important role in phase II detoxification mechanisms. Its activity is crucial to mitigate the lipid peroxidation products accumulated in tissues (33). Thus, the reduction in the activity levels of GST indicates a failure of removal of lipid peroxidation products in tissues. Interestingly, the activity levels of XOD an enzyme that plays an important role in detoxification mechanisms was significantly increased in selected tissues of $\mathrm{Cd}, \mathrm{AH}$ and $\mathrm{Cd}+\mathrm{AH}$ treated fishes. Previously, it has been shown that XOD levels alter in kidney tissue of fishes during Cd-induced stress (28). It is well known that SOD and CAT act as cyclic enzymes to mitigate superoxides and hydroperoxides (32). However, failure of these enzymes subsequently leads to accumulation of superoxides and hydroperoxides which in turn negatively target structural integrity of tissues. Thus, the failure of SOD and enhanced activity of XOD, a detoxification enzyme that leads to superoxides might also responsible for the accumulation of superoxides which eventually targets catalase and its expression. Furthermore, all these sequential cascade of events leads to accumulation of hydrogen peroxide in the tissues which in turn targets SOD and its expression.

One of the important findings of the present study indicates that AgNPs showed reversal effects on Cd, $\mathrm{AH}$ and $\mathrm{Cd}+\mathrm{AH}$ induced alterations in pro-and antioxidant status in gills, kidneys and liver of fishes, Catla catla. No studies so for reported the ability of AgNPs to protect fishes against pro-and anti-oxidant changes induced by dual stressors such as $\mathrm{Cd}$ and $\mathrm{AH}$. Perhaps, the present study was the first to demonstrate the protective effect of AgNPs against $\mathrm{Cd}-$, $\mathrm{AH}-$ and $\mathrm{Cd}+\mathrm{AH}-\mathrm{induced}$ altered status in the activity levels of antioxidant enzymes such as SOD, CAT, XOD and GST in fishes, Catla catla. Although, the exact mechanism(s) of action of AgNPs induced inhibition of LPx levels in selected tissues of $\mathrm{Cd}, \mathrm{AH}, \mathrm{Cd}+\mathrm{AH}$ treated fishes are not well defined, it has been suggested that maintenance of structural integrity of tissues might be one of the plausible reasons which could sustain a balance between generation of ROS and antioxidant enzymes. It is unequivocal that improper management of mitochondrial electron transport and respiratory chain events are at least in part result in generation of ROS. Previous studies from our laboratory indicate that AgNPs showed enhanced activity levels of mitochondrial marker enzyme succinate dehydrogenase in AH infected gills, 
kidney and liver of fishes indicating the normal functional activity of mitochondria. Recently, studies of Xie et al. and $\mathrm{Su}$ et al. $(24,25)$ reported that Titanium dioxide nanoparticles $\left(\mathrm{TiO}_{2} \mathrm{NPs}\right)$ protected brain tissue from oxidative stress induced by organophosphorus pesticide, phoxim in silk worm, Bombyx mori. The same authors indicated that $\mathrm{TiO}_{2} \mathrm{NPs}$ suppressed oxidative stress in selected tissues of insects might be due to regulation of expression of genes such as caspases which are believed to be important in oxidative stress and mitochondria and respiratory chain $(24,25)$. Recently, studies of Oliveira et al. (34), indicated that AgNPs with organic additives such as (1) 5-Aminoisoquinoline, (2) 7-amino-4-methylcoumarin, and (3) 2-Aminoanthraceneas did not elicit same responses in pro- (malondialdehyde levels) and antioxidant enzymes such as CAT and GST in intestine and liver tissues of gold fish, Carassius auratus. The same authors reported that AgNPs with organic additive 1 and 2 showed no changes in LPx levels and the activity levels of antioxidant enzymes such as GST and CAT in intestine and liver of gold fishes whereas AgNPs with organic additive 3 showed oxidative stress in gold fishes, suggesting the importance of surrounding environment of AgNPs. Moreover, it has also been shown that AgNPs with organic additive 1 exhibited cytotoxicity of mammalian cells, HepG2 cells as compared to AgNPs with organic additive 3 which exhibited lower cell toxicity of HepG2 cells (34). It is noteworthy to mention that $\mathrm{TiO}_{2} \mathrm{NPs}$ enhanced the antioxidant system against phoxim-induced oxidative stress in Bombyx mori (25). Further, it has been suggested that $\mathrm{TiO}_{2} \mathrm{NPs}$ have ability to act at the level of expression of resistancerelated genes and their proteins, including those encoding SOD, CAT, GPX, and GST, which in turn mitigate ROS in B. mori larvae under BmNPV infection (35). In the present study, AgNPs mediated protection seems to be indirect. We hypothesize that AgNPs through unknown mechanisms maintain structural integrity of tissues which in turn sustains intrinsic antioxidant status in $\mathrm{Cd}$ exposed fishes; in addition, AgNPs through antimicrobial properties mitigate $\mathrm{AH}$ colonization which in turn inhibits $\mathrm{AH}$-induced negative effects on proand antioxidant status in selected tissues of fishes. Further, studies aiming at molecular aspects related to proand antioxidant system such as expression of caspases are in progress in our laboratory to explore AgNPs induced protection against $\mathrm{Cd}, \mathrm{AH}, \mathrm{Cd}+\mathrm{AH}$-induced oxidative stress.

\section{CONCLUSION}

The present study addresses the therapeutic utility of AgNPs against dual stress factors (metal toxicity: $\mathrm{Cd}$ and bacterial infections: Aeromonas hydrophila infections) in vivo. This provides the first evidence that $\mathrm{Cd}+\mathrm{AH}$ at least in part targets pro-and anti-oxidant status and it could seriously compromise fish health. Our results also indicated that AgNPs protects fishes against dual stress $(\mathrm{Cd}+\mathrm{AH})$-induced oxidative stress. Although, the recovery was observed in pro- and anti-oxidant status in AgNPs supplemented experimental groups $(\mathrm{Cd}, \mathrm{AH}$ and $\mathrm{Cd}+\mathrm{AH})$, the effect was partial. Thus, usage of AgNPs as therapeutic candidates in aquaculture needs further research. On the other hand, the present study provides a platform and paves a way for young researchers to meet the gaps and challenges in this field. Thus, further research in fish model(s) developed will strengthen and expand the knowledge on AgNPs and its cross-talk with fish physiology during dual stress conditions. Finally, studies in this direction could help to shape the application of nano-based candidates in aquaculture.

\section{ACKNOWLEDGEMENTS}

The authors thank Head, Department of Aquaculture, S. V. University, Tirupati-517 502 and Head, Department of Soil Sciences, S.V. Agricultural College Tirupati-517 502, AP, India for providing laboratory facilities and silver nanoparticles, respectively.

[1]. K. Anjani, P.K. Joshi and S.B. Pratap, Fisheries Sector in India: An Overview of Performance, Policies and Programmes, in K. Anjani, K.K. Pradeep and P.K. Joshi (Eds.), A Profile of People, Technologies and Policies in Fisheries Sector in India, (2003) $1-16$.

[2]. B. Mohanty, S. Mohanty, J. Sahoo and A. Sharma, Climate Change: Impacts on Fisheries and Aquaculture, in S. Simard (Ed.), Climate Change and Variability, (Europe: Sciyo, Intech, 2010) 1-486.

[3]. M. J. A. Sarkar and M. M. Rashid, Pathogenicity of the bacterial isolate Aeromonas hydrophila to catfishes, carps and perch, Journal of Bangladesh Agricultural University 10(1), 2012, 157-161.

[4]. S. Ayyappan, and J.K. Jena, Grow-out production of carps in India, Journal of Applied Aquaculture 13(3/4), 2003, 251-282.

[5]. J.L. Torres, M. Sharif and A.T. Law, Identification and virulence screening of Aeromonas spp. isolated from healthy and epizootic ulcerative syndrome (EUS) infected fish, in R. Hirano, and I. Hanyu (Eds.), Proceedings of the Second Asian Fisheries Forum, (Asian Fisheries Society, Manila, Philippine, 1996) pp. 663-668.

[6]. H.A.C.C. Perera, and A. Pathiratne, Enhancement of immune responses in Indian carp, Catla catla, following adistration of levamisole by immersion, in M.G. Bondad-Reantaso, C.V. Mohan, M. Crumlish, and R.P. Subasinghe, (Eds.), Diseases in Asian Aquaculture VI. Fish Health Section, (Asian Fisheries Society, Manila, Philippines, 2008) pp 505.

[7]. B. Kaleeswaran, S. Ilavenil, S. Ravikumar, Changes in biochemical, histological and specific immune parameters in Catla catla (Ham.) by Cynodon dactylon (L.), Journal of King Saud University - Science 24, 2012, 139-152

[8]. T. Kiran Reddy, S. Janardana Reddy and T.N.V.K.V. Prasad. Effect of silver nanoparticles on energy metabolism in selected tissues of Aeromonas hydrophila infected indian major carp, Catla catla. IOSRPHR Journal 3, 2013, 49-55.

[9]. L. Jarup. Hazards of heavy metal contamination. British Medical Bulletin 68, 2003, 167-182. 
[10]. M.A. Peraja, F. Ayala-Fierro, D, Barber, R. Casarez, L.T. Rael. Effects of micro nutrients on metal toxicity. Environ. Health. Perspect. 106 (1), 1998, 203-216.

[11]. T. Vandevelde, H. Renner, G. Schlamp, Silver, silver compounds, and silver alloys. Ullmann's Encylopedia of Industrial Chemistry. chapter 10. (New York, NY, USA: John Wiley \& Sons, 2009)

[12]. J.S. Kim, E. Kuk, K.N. Yu, J.H. Kim, S.J. Park, H.I.Lee, S.H. Kim, S.J. Park, Y.H. Park, C.Y. Hwang, Y.K. Kim, Y.S. Lee, D.H. Jeong, M.H. Cho, Antimicrobial effects of silver nanopaticles. Nanomedicine: Nanotechnology Biology and Medicine. 3, 2007, 95-101.

[13]. M. Soltani, M. Ghodratnema, H. Ahari, H.A. Ebrahimzadeh Mousavi, M. Atee, F. Dastmalchi, J. Rahmanya, The inhibitory effect of silver nanoparticles on the bacterial fish pathogens Streptococcus iniae Lactococcus garvieae Yersinia ruckeri Aeromonas hydrophila, International Journal of Veterinary Research 3,2009, 137-142.

[14]. T.M. Scown, E.M. Santos, B.D. Johnston, B. Gaiser, M. Baalousha S. Mitov, J.R. Lead, V. Stone, T.F. Fernandes, M. Jepson et al., Effects of aqueous exposure to silver nanoparticles of different sizes in rainbow trout. Toxicological Sciences 115, 2010, $521-534$.

[15]. W.H. Habig, M.J. Dabit, W.B. Jacoby. Glutathione S-transferases: the first enzymatic step in mercapturic acid formation. J. Biol. Chem. 249, 1974, 7130-7139.

[16]. H.P. Misra, I, Fridovich. The role of Superoxide anion in the autooxidation of epinephrine and a simple assay for superoxide dismutase J K. Biol chem. 247, 1972, 3170-3175.

[17]. H, Aebi. Catalase Methods Enzymol. 105, 1984, 125-126.

[18]. T.N. Srikantan, C.R. Krishnamurthy. 1955. Tetrazolium test for dehydrogenases. J. Sci. Ind. Res. 14, 1955, 206-207.

[19]. O. Hiroshi, N. Ohisi and K. Yagi, Assay for lipid peroxides in animal tissues by TBA reaction. Analytical Biochemistry 95, 1979,351-358.

[20]. H. Lowry, N.I. Rosebrough, A.L. Far and R.J. Randall, 1951. Protein measurement with folin phenol reagent, Journal of Biological Chemistry 193, 1951, 265-275.

[21]. R.D. Handy. FSBI Briefing paper: Nanotechnology in fisheries and aquaculture. Fisheries Society of the British Isles, $2012,1-29$.

[22]. K. Park, G. Tuttle, F. Sinche, S. L. Harper. Stability of citrate-capped silver nanoparticles in exposure media and their effects on the development of embryonic zebrafish (Danio rerio). Arch Pharm Res. 36(1), 2013, 125-133.

[23]. R. Ramesh, P. Kavitha, N. Kanipandian, S. Arun, R. Thirumurugan, P. Subramanian. Alteration of antioxidant enzymes and impairment of DNA in the SiO2 nanoparticles exposed zebra fish (Danio rerio). Environ Monit Assess 185, 2013, 5873-5881.

[24]. Y. Xie, B. Wang, F. Li, L. Ma, M. Ni, W. Shen, F. Hong, B. Li. Molecular Mechanisms of Reduced Nerve Toxicity by titanium dioxide nanoparticles in the phoxim-exposed Brain of Bombyx mori. Plos One. 9(6), 2014, e101062. doi:10.1371/journal.pone.0101062

[25]. Su JJ, Li B, Cheng S, Zhu Z, Sang XZ, et al. Phoxim-induced damages of Bombyx mori larval midgut and titanium dioxide nanoparticles protective role under phoxim-induced toxicity. Environmental toxicology. 2013, DOI:10.1002/tox.21866.

[26]. E, Brucka-Jastrzębska. The effect of aquatic cadmium and lead pollution on lipid peroxidation and superoxide dismutase activity in freshwater fish. Polish J. of Environ. Stud.19, 2010, 1139-1150

[27]. A. Dabas, N. S. Nagpure, R. Kumar, B. Kushwaha, P. Kumar, W. S. Lakra. Assessment of tissue-specific effect of cadmium on antioxidant defense system and lipid peroxidation in freshwater murrel, Channa punctatus. Fish Physiol Biochem 38, 2012, 469482.

[28]. P. Siraj Basha and A. Usha Rani. Cadmium-induced antioxidant defense mechanism in freshwater teleost Oreochromis mossambicus (Tilapia). Ecotoxicology and Environmental Safety 56, 2003, 218-221.

[29]. A.M. Pruski, D.R. Dixon. Effects of cadmium on nuclear integrity and DNA repair efficiency in the gill cells of Mytilus edulis L. Aquat. Toxicol. 57, 2002, 127.

[30]. S.J. Stohs, D. Hagchi, E. Hassoun, M. Bagshi. Oxidative mechanisms in the toxicity of chromium and cadmium ions. J Environ Pathol Toxicol Oncol 19, 2000, 201-213.

[31]. H. Tkachenko, N. Kurhaluk, A. Andriichuk, E. Gasiuk, S. Beschasniu. Oxidative stress biomarkers in liver of sea trout (salmo trutta m. trutta 1.) affected by ulcerative dermal necrosis syndrome. Turkish Journal of Fisheries and Aquatic Sciences 14, 2014, 391-402.

[32]. I. Fridovich. Biological effects of the superoxide radical. Arch Biochem Biophys 247, 1986, 1-11.

[33]. P. Morrissey, P.J. O'Brien. Selenium-independent glutathione peroxidase activity in rabbit liver. Can J. Biochem. 58, 1980, 1012-1017.

[34]. E. Oliveira, H.M. Santos, J. Garcia-Pardo, M. Diniz, J. Lorenzo, B. Rodríguez-González, J. L. Capelo, C. Lodeiro. Synthesis of functionalized fluorescent silver nanoparticles and their toxicological effect in aquatic environments (Goldfish) and HEPG2 cells. Front Chem. 2013; 1: 29. doi: 10.3389/fchem.2013.00029

[35]. B. Li, Y. Xie, Z. Cheng, J. Cheng, R.P. Hu, S.X. Gui et al. BmNPV resistance of silkworm larvae resulting from the ingestion of $\mathrm{TiO}_{2}$ nanoparticles. Biol Trace Elem Res 150, 2012, 221-228. 
Table 1: $\quad$ Effect of silver nanoparticles (AgNPs) on lipid peroxidation and the activity of selected antioxidant enzymes in selected tissues of fishes treated with individual or in combination of cadmium (Cd) and Aeromonas hydrophila $(\mathrm{AH})$

\begin{tabular}{|c|c|c|c|c|c|c|c|c|}
\hline \multirow{2}{*}{ Organ } & \multirow{2}{*}{ Control } & \multicolumn{7}{|c|}{ Experimental Groups } \\
\hline & & $\mathrm{Cd}$ & $\mathrm{AH}$ & $\mathrm{AgNPS}$ & $\mathrm{AH}+\mathrm{Cd}$ & $\mathrm{AH}+\mathrm{AgNPS}$ & $\mathrm{Cd}+\mathrm{AgNPs}$ & $\mathrm{AH}+\mathrm{Cd}+\mathrm{AgNPs}$ \\
\hline \multicolumn{9}{|c|}{ Lipid peroxidation (nmoles of MDA formed/hour/g tissue) } \\
\hline Liver & $3.21 \pm 0.79$ & $9.79 * \pm 0.97$ & $9.21 * \pm 0.81$ & $4.54^{\mathrm{ns}} \pm 0.78$ & $15.63 * \pm 1.24$ & $7.27 * \pm 0.79$ & $7.21 * * \pm 0.64$ & $13.41 * \pm 0.45$ \\
\hline Kidney & $6.45 \pm 0.24$ & $12.22 * \pm 0.97$ & $11.51 * \pm 0.94$ & $7.21^{\mathrm{ns}} \pm 1.21$ & $16.31 * \pm 2.47$ & $9.27 * \pm 0.75$ & $9.27 * * \pm 0.54$ & $12.98 * \pm 0.95$ \\
\hline Gills & $4.41 \pm 0.74$ & $10.64 * \pm 0.84$ & $10.41 * \pm 0.97$ & $5.63^{\mathrm{ns}} \pm 1.01$ & $16.57 * \pm 3.69$ & $7.14^{*} \pm 0.85$ & $8.87 * * \pm 0.67$ & $13.75 * \pm 0.47$ \\
\hline \multicolumn{9}{|c|}{ Superoxide dismutase (Units/mg protein) } \\
\hline Liver & $0.82 \pm 0.071$ & $0.61 * \pm 0.010$ & $0.59 * \pm 0.009$ & $0.91^{\mathrm{ns}} \pm 0.039$ & $0.41 * \pm 0.004$ & $0.71 * \pm 0.004$ & $0.72 * \pm 0.005$ & $0.56^{*} \pm 0.008$ \\
\hline Kidney & $0.79 \pm 0.065$ & $0.52 * \pm 0.009$ & $0.58 * \pm 0.005$ & $0.86^{\mathrm{ns}} \pm 0.024$ & $0.32 * \pm 0.009$ & $0.67 * \pm 0.002$ & $0.58^{*} \pm 0.007$ & $0.57^{*} \pm 0.011$ \\
\hline Gills & $0.87 \pm 0.058$ & $0.59 * \pm 0.0045$ & $0.62 * 0.007$ & $0.94^{\mathrm{ns}} \pm 0 . .035$ & $0.49 * \pm 0.005$ & $0.75 * 0.007$ & $0.67 * \pm 0.012$ & $0.61 * \pm 0.009$ \\
\hline \multicolumn{9}{|c|}{ Xanthine oxidase ( $\mu$ moles of formazan formed / mg protein / hour) } \\
\hline Liver & $0.09 \pm 0.0007$ & $0.17 * \pm 0.0021$ & $0.21 * \pm 0.0017$ & $0.10^{\mathrm{ns}} \pm 0.0009$ & $0.29 * \pm 0.0015$ & $0.12 * \pm 0.0011$ & $0.14^{*} \pm 0.0017$ & $0.21 * \pm 0.0011$ \\
\hline Kidney & $0.14 \pm 0.0011$ & $0.23 * \pm 0.0034$ & $0.24 * \pm 0.0014$ & $0.16^{\mathrm{ns}} \pm 0.0018$ & $0.27 * \pm 0.0019$ & $0.17 * \pm 0.0024$ & $0.18^{*} \pm 0.0014$ & $0.22 * \pm 0.0016$ \\
\hline Gills & $0.31 \pm 0.0012$ & $0.42 * \pm 0.0018$ & $0.47 * \pm 0.0018$ & $0.32^{\mathrm{ns}} \pm 0.0017$ & $0.51 * \pm 0.0021$ & $0.37^{*} \pm 0.0012$ & $0.38^{*} \pm 0.0015$ & $0.41 * \pm 0.0019$ \\
\hline \multicolumn{9}{|c|}{ Catalase ( $\mu$ moles of hydrogen peroxide decomposed $/ \mathrm{mg}$ protein $/ \mathrm{min}$ ) } \\
\hline Liver & $0.89 \pm 0.009$ & $0.51 * \pm 0.008$ & $0.41 * \pm 0.018$ & $0.92^{\mathrm{ns}} \pm 0.019$ & $0.22 * \pm 0.004$ & $0.60 * \pm 0.016$ & $0.61 * \pm 0.013$ & $0.51^{*} \pm 0.006$ \\
\hline Kidney & $1.89 \pm 0.011$ & $0.98 * \pm 0.015$ & $1.15^{*} \pm 0.012$ & $1.91^{\mathrm{ns}} \pm 0.012$ & $0.77 * \pm 0.019$ & $1.37 * \pm 0.015$ & $1.21 * \pm 0.014$ & $1.01 * \pm 0.019$ \\
\hline Gills & $0.45 \pm 0.008$ & $0.26^{*} \pm 0.006$ & $0.27 * \pm 0.009$ & $0.47^{\mathrm{ns}} \pm 0.011$ & $0.21 * \pm 0.005$ & $0.33 * \pm 0.006$ & $0.34 * 0.007$ & $0.29 * \pm 0.008$ \\
\hline \multicolumn{9}{|c|}{ Glutathione-S-transferase (nmoles of GSH-CDNB conjugate formed/min/mg protein) } \\
\hline Liver & $0.35 \pm 0.002$ & $0.24 * \pm 0.012$ & $0.23^{*} \pm 0.012$ & $0.37^{\mathrm{ns}} \pm 0.007$ & $0.19 * \pm 0.006$ & $0.46^{*} \pm 0.002$ & $0.42^{*} \pm 0.0034$ & $0.25 * \pm 0.005$ \\
\hline Kidney & $0.91 \pm 0.006$ & $0.71 * \pm 0.009$ & $0.61 * \pm 0.009$ & $0.97^{\mathrm{ns}} \pm 0.006$ & $0.49 * \pm 0.004$ & $0.84 * \pm 0.004$ & $0.81^{*} \pm 0.0031$ & $0.66^{*} \pm 0.004$ \\
\hline Gills & $1.45 \pm 0.009$ & $0.82 * \pm 0.019$ & $0.72 * \pm 0.019$ & $1.47^{\mathrm{ns}} \pm 0.005$ & $0.57 * \pm 0.009$ & $0.98 * \pm 0.006$ & $1.11^{*} \pm 0.0048$ & $0.89 * \pm 0.007$ \\
\hline
\end{tabular}

For evaluation of ' $\mathrm{p}$ ', for $\mathrm{Cd}$-exposed, $\mathrm{AH}$ infected, $\mathrm{Cd}+\mathrm{AH}$ treated and $\mathrm{AgNPs}$, untreated fishes served as controls; for $\mathrm{Cd}+\mathrm{AgNPs}, \mathrm{AH}+\mathrm{AgNPs}$ and $\mathrm{Cd}+\mathrm{AH}+\mathrm{AgNPs}$ treated fishes, $\mathrm{Cd}$-exposed, $\mathrm{AH}$ infected and $\mathrm{Cd}+\mathrm{AH}$ treated fishes served as controls, respectively.

*significant at $\mathrm{p}<0.01 ; * *$ significant at $\mathrm{p}<0.05$ 